\title{
'There are no Victims Here': Ethnography of a reintegration shelter for survivors of trafficking in Bangladesh
}

Diya Bose

\begin{abstract}
This article, based on nine months of ethnographic data from a reintegration shelter for survivors of trafficking in Bangladesh, examines the tensions between claims of empowerment and the disempowering practices that undermine an organisation's liberatory objective. The author documents how the leadership and other staff of an anti-trafficking NGO engage in regulating survivors' desires, directing their desires by demanding that they perform a desire to engage in particular modes of self-improvement, and rebabilitating their desires to seek gender-conforming occupations. These three strategies together constitute disciplining desire, which I identify as a process of othering of poor Third World women and cultivating an ideal survivor subjectivity that conforms to gender and class expectations in the name of 'reintegration'. This account encourages researchers to critically consider the micro-interactions that undermine the emancipatory goals within women's empowerment regimes in the Global South.
\end{abstract}

Keywords: anti-trafficking, empowerment, gender, labour, rehabilitation, South Asia, women

Please cite this article as: D Bose, “'There are no Victims Here”: Ethnography of a reintegration shelter for survivors of trafficking in Bangladesh', Anti-Trafficking Review, issue 10, 2018, pp. 139-154, www.antitraffickingreview.org

\section{Introduction}

Café Mukti, or Café Freedom, was an unremarkable small coffee stand on the first floor of the International Organization for Migration (IOM) office in Dhaka, Bangladesh, staffed by a group of remarkable young women. On a chilly January morning, when I approached the counter with an American friend, all three workers, aged between 17 and 22, dressed sharply, in starched blue and white salwar kameez and baseball caps with 'Café Mukti' stitched on top, met us with cheerful greetings in English. I knew that the greetings were from a script because I had helped them rehearse it the night before at a shelter home for survivors of various forms of trafficking, including into the sex trade, domestic work and camel jockeying. These women were three of the 120 survivors, that also included young boys and girls, who had been repatriated to Bangladesh from India, Indonesia, Malaysia and various countries in the Middle East, after having been rescued from exploitative labour contexts. I had come to know many of the shelter's residents over the nine months between 2009 and 2010, when I volunteered for the National Women's Association (NWA), ${ }^{1}$ which runs the shelter. These women shared with me their dreams of getting an education, learning a trade, or running their own businesses. They also dreamt of falling in love, getting married, and even travelling to the same countries from where they had been repatriated, but this time, on their own terms.

For over three decades, the NWA has been working in Bangladesh to promote women's equality and end violence against women. Using nine months of ethnographic observations, I find that instead of helping survivors forge tools for social empowerment and economic independence, NWA labours to re-educate survivors in how to align their ambitions and activities with the goal of becoming 'good women', which for lower-class women means being chaste and humble, stripped of desires. I find that the staff prioritises individualised treatment or rehabilitation approaches that focus on personal change rather than advocating for structural interventions. Despite the use of empowerment rhetoric that champions survivors and respect for their agency, I argue that the leadership and staff at the NWA view the women in their care as inherently vulnerable due to their lower-class position and status as formerly trafficked women, requiring protection from

1 Name changed to protect subjects. 
their desires. In this article, I document the paradox between NGO actors' stated goals of empowering survivors of trafficking and their actual practices of socialising survivors to recognise their perceived position at the bottom of a social hierarchy. To this end, I distinguish three strategies that NWA employs to control the desires of women under their care. These strategies are differentially enacted based on their role in the organisation: leadership sets the broader tone and agenda while case-workers shape the everyday lives of survivors. In what follows, I demonstrate how NWA leadership and staff engage in regulating survivors' desires, directing their desires by demanding that survivors perform a desire to engage in particular modes of selfimprovement, and rehabilitating their desires to seek gender-conforming occupations. These three strategies together constitute disciplining desire, which I identify as a process of othering of poor Third World women and cultivating an ideal survivor subjectivity that conforms to gender and class expectations in the name of 'reintegration'.

\section{Background}

Bangladesh is an ideal location to examine this issue since rehabilitation programmes for displaced women have been critical to its foundation as a country. In the 1971 civil war between East and West Pakistan, which eventually resulted in the creation of Bangladesh, the Pakistani military engaged in mass rape as a strategy of war. In the post-Independence period, the government established programmes to aid women who had been raped and displaced during the conflict and whose families had largely rejected them. Although the state intervened to protect these survivors of war, rehabilitation programmes were steeped in the traditional moral code, and disciplining women considered deviant formed the subtext of the 'rehabilitation'. However, neither the government nor these programmes made any attempt to address the underlying cultural sources of stigma which endured. Since the 1970 s, state-run rehabilitation programmes have targeted various groups, ranging from landless women to female prisoners and prostitutes, and, more recently, survivors of trafficking.

NWA has often been a vocal critic of the state's criminalisation and displacement of sex workers and has advocated for greater attention to the trafficking of men, women and children in non-sex work-related sectors. NWA insists that it treats those under its care as survivors rather than as victims. As the staff explained to me, a victim is someone who lacks agency and must be protected even at the cost of personal autonomy, whereas a survivor is someone who can overcome great difficulties through personal strength and resilience. This discourse of survivorship and history of pro-sex worker rights stance seemingly sets this Bangladeshi feminist organisation apart from other anti-trafficking organisations. ${ }^{2}$ Moreover, NWA rejects the term 'rehabilitation' as it implies that it is the individual who is in need of transformation. Instead, the organisation prefers the term 'reintegration', indicating that it seeks to address structural barriers, such as gender and economic inequality. However, my observations revealed that while NWA indeed champions women's right to work and migrate on the policy advocacy level, the legacy of past rehabilitation programmes continues in their own shelter home.

In this paper, I build on the critical literature on anti-trafficking programmes by focusing on a reintegration shelter in the Global South to show how stated goals of empowerment for survivors are undermined by practices steeped in gender and class-based hierarchies. I further draw on the sociological concept of total institution to theorise the micro-interactions inside the shelter.

\section{Anti-Trafficking Programmes and the Concept of Victimhood}

I use the category of trafficked women as an analytical anchor despite contestations over the definition of trafficking and the diverse range of experiences of the women at the shelter, including some who claimed to have been voluntary sex workers and others who were trafficked for domestic labour. There is a burgeoning literature that attests to how anti-trafficking programmes can isolate, imprison, and further marginalise women labelled as trafficked after they have been rescued, ${ }^{3}$ and how there exists the practice to cite the vulnerability of

2 K Kempadoo, 'The Modern-Day White (Wo)Man's Burden: Trends in anti-trafficking and anti-slavery campaigns', Journal of Human Trafficking, vol. 1, issue 1, 2015, pp. 8-20.

3 N Sharma, 'Anti-Trafficking Rhetoric and the Making of a Global Apartheid', NWS A Journal, vol. 17, issue 3, 2005, pp. 88-111. 
trafficked women in order to justify locking them up. ${ }^{4}$ Research from the US, UK and the Netherlands has demonstrated that an anti-immigrant bias undergirds anti-trafficking policies and as a result, often women who have been 'rescued' from trafficking are incarcerated and/or sent back to their countries of origin. ${ }^{5}$ However, less attention has been paid to what happens after such repatriation. By investigating micro-interactions inside a shelter, this article shows how class and gender hierarchies shape these women's lives after trafficking.

Approaches to trafficking range from strictly prostitution abolitionist to those that view trafficking on a continuum of migration experiences, as a human rights issue, or within a pro-sex worker rights and labour framework. ${ }^{6}$ Some consider it a form of 'corrupted migration', ${ }^{7}$ as 'modern day slavery', ${ }^{8}$ or 'female sexual slavery'. Scholars of anti-trafficking find that the prostitution abolitionist discourse has long conflated trafficking with sex work and have likened it to a moral crusade. ${ }^{10}$ In contrast, a growing international sex worker rights movement has emerged alongside feminist postmodern, postcolonial, and transnational theorising to challenge abolitionist feminist claims that sex work is fundamentally oppressive towards women. ${ }^{11}$ These feminists have pointed out that conflating sexual labour with sexual violence flattens women's experience to narratives of victimhood. ${ }^{12}$ Even when confronted with the reality of trafficked women who flee from rehabilitation institutions, rather than reassessing their own assumptions, rescuers often attribute a false consciousness to the victims, arguing that they are addicted to the conditions of their oppression..$^{13}$ As Cojocaru argues, the abolitionist victimhood framework justifies the exclusion of those who join the sex trade voluntarily and leads to objectification of trafficked victims by their rescuers. ${ }^{14}$ Furthermore, they argue that the 'rescue' model seeks to liberate women from their traffickers without challenging social hierarchies of gender, race and nationality since the rescuers are often Western activists and government officials and those who require protection are often women who are racial and national others. ${ }^{15}$

Since 2001, the United States government has been pressuring countries to implement anti-trafficking measures through its annual Trafficking in Persons (TIP) Report, with particular focus on arrests, investigations and prosecutions. Non-compliance with the TIP Report standards can lead to sanctions and withdrawal of aid, so governments especially in low-income countries have prioritised a criminal justice approach to trafficking. In order to comply with the TIP Report's requirement to show greater numbers of arrests and prosecution, governments encourage law enforcement to enlist the aid of NGOs. ${ }^{16}$ This means that NGOs not only give advice and provide training to law enforcement officials, they are also frequently present at police raids of brothels. The police hand over those they identify as 'victims' (often based on whether they appear below the age of 18) to NGOs for 'safe custody', pending further investigation. Thus, rather than acting as watchdogs to hold the police accountable to gender-sensitive practices and minimise police brutality, NGOs become partners in law-enforcement activities. ${ }^{17}$ What follows the 'rescue' has expanded considerably, and NGOs have become

4 J Musto, 'Carceral Protectionism and Multi-Professional Anti-Trafficking Human Rights Work in the Netherlands', International Feminist Journal of Politics, vol. 12, issue 3-4, 2010, pp. 381-400.

5 K Sharapov, “Traffickers and Their Victims”: Anti-trafficking policy in the United Kingdom', Critical Sociology, vol. 43, issue 1, 2017, pp. 91-111.

6 Musto, 2010.

7 B Anderson and J O'Connell Davidson, Is Trafficking in Human Beings Demand Driven? A pilot-study, International Organization for Migration, Geneva, 2003.

8 K Bales, Disposable People: New slavery in the global economy, University of California Press, Berkeley, 2004.

9 K Barry, Female Sexual Slavery, New York University Press, New York, 1979; D Hughes, "The "Natasha" Trade: Transnational sex trafficking', National Institute of Justice Journal, 2000, pp. 1-9.

10 J Doezema, 'Prevent, Protect and Punish' in J Doezema, Sex Slaves and Discourse Masters: The construction of trafficking, Zed Books, 2010, pp. 106-123; S Limoncelli, The Politics of Humanitarianism: States, reformers and the international movement to combat the traffic in women, 1875-1960. PhD Dissertation, University of California, Los Angeles, 2006.

11 K Kempadoo, Global Sex Workers: Rights, resistance and redefinition, Routledge, London, 1998.

12 C Cojocaru, 'Sex Trafficking, Captivity, and Narrative: Constructing victimhood with the goal of salvation', Dialectical Anthropology, vol. 39, issue 2, 2015, p. 183.

13 G Soderlund, 'Running from the Rescuers: New US crusades against sex trafficking and the rhetoric of abolition', NWS A Journal, 2005, pp. 64-87.

14 Cojocaru.

15 Kempadoo, 2015.

${ }^{16} \mathrm{~J}$ Chuang, 'Beyond a Snapshot: Preventing human trafficking in the global economy', Indiana Journal of Global Legal Studies, vol. 13, issue 1, 2006, pp. 137-63.

17 Musto, 2010. 
important arbiters of rescue and rehabilitation. Feminist scholars have raised concerns about how the politics of rescue and care reproduce rather than disrupt social hierarchies, including those of gender, race, and class. ${ }^{18}$

\section{Reintegration shelter as a total institution}

To understand the micro-interactions within the shelter, I draw on Goffman's concept of total institutions. Erving Goffman defined a 'total institution' as 'a place of residence and work where a large number of likesituated individuals, cut off from the wider society for an appreciable period of time, together lead an enclosed, formally administered round of life'. ${ }^{19}$ Goffman argues that while the public perceives such institutions as spaces that seek to rehabilitate inmates, they generally function as 'storage dumps' for particular populations. Thus, he finds that the contradiction between the institution's publicly stated goals and its methods of managing the population is inherent to total institutions. Michel Foucault finds such institutions as characteristic of the modern era, in which government power and institutional power structures constitute 'biopower', 'an explosion of numerous and diverse techniques for achieving the subjugation of bodies and the control of populations'.$^{20}$ Foucault's conception of power as not simply repressive, but a dispersive process that produces realities offers a way to analyse micro-interactions inside total institutions. By applying a lens of biopower to a reintegration shelter for trafficked women in the Global South, I identify how the institution engages in a process of disciplining desire that reduces agency and independence and discursively produces the ideal survivor, that is, the disciplined survivor, in contrast to the dangerous deviant.

\section{Methods}

From September 2009 to June 2010, I conducted this ethnography of reintegration strategies in Dhaka, Bangladesh, with the support of a Fulbright Grant. NWA was an ideal host because it is a prominent women's rights organisation with key links to government officials and law enforcement agencies and has programmes in underserved, rural areas.

In my research, I employed a combination of thirteen semi-structured interviews, focus group meetings, and participant observation. As a participant observer, I worked as a volunteer at the main office for three days a week in the mornings, translating reports and press releases and spent my afternoons observing and doing ethnographic interviews at the shelter. I also stayed in a spare room at the shelter for three weeks which allowed me to witness first-hand daily life at the shelter. ${ }^{21}$ Being an American scholar with Bengali-Indian heritage secured my Insider/Outsider positionality, on the one hand, and, on the other, compelled me to remain sensitive to and examine how my presence impacted the fieldwork.

My involvement with the organisation's day-to-day work was initially a double-edged sword when it came to interviewing survivors. Many of them initially saw me as an NGO staff member, and I had to take their answers with a grain of salt. However, by visiting the survivors almost every day and keeping them company while they worked in the kitchen or babysat the youngest children, I was able to eventually gain their trust. Living with the survivors at the shelter was particularly helpful because they could come talk to me after all the case managers had left and, to some extent, I could experience with them what life was like once all the iron doors were locked at 8 p.m. The residents of the shelter ranged from the age of two to 25 , with majority of the women between 16 and 21. In the shelter, I interviewed thirteen women, two of whom had infants. I also conducted semi-structured interviews with eight staff members, including the executive director, three programme officers, one counsellor and several board members and lower-level staff members. My data analysis is based on the ethnographic notes and interviews I transcribed and translated. As such, the quotes in the following sections should be seen as approximations.

18 J Musto, 'What's in a Name? Conflations and contradictions in contemporary US discourses of human trafficking', Women Studies International Forum, vol. 32, issue 4, 2009, pp. 281-87; M Ticktin, 'The Gendered Human of Humanitarianism: Medicalising and politicising sexual violence’, Gender \& History, vol. 23, issue 2, 2011, pp. $250-65$.

19 E Goffman, 'On the characteristics of total institutions' in National Research Council, Symposium on Preventive and Social Psychiatry, The National Academies Press, Washington DC, 1961, pp. 43-84.

20 M Foucault, Power/Knowledge: Selected interviews and other writings 1972-1977, Harvester, Brighton, 1979.

21 My research is based on hand written notes I took during interviews and after observations, which I typed up in English every week. I closely re-read the field notes and interview transcripts to identify patterns and themes. 
In terms of my data analysis, I adopted an abductive theory approach which calls for the active engagement of the researcher's positionality as well as an openness to surprising evidence. ${ }^{22}$ As opposed to the grounded theory approach, in which the researcher is aided only by observations, paying attention to patterns and repeated information, the abductive approach refers to the creative production of hypotheses based on surprising evidence to construct theory.

\section{'There are no Victims Here': The organisation's reintegration discourse and actual practices}

NWA leadership, in their official reports, media appearances, and interviews, emphasise the strength and agency of trafficked women and the right of lower-income Bangladeshi women to safe migration. They insist that they treat the women in their care not as pitiful, helpless victims in need of rescue, but active agents of change who can take control of their lives and decide their own fate.

Yet, this official rhetoric contrasts sharply with the actual treatment of survivors by the staff in the shelter. The case managers there view the women as being at the same time childlike, innocent victims and sexual deviants. This contrast stems from a tension between discourses of empowerment that are influenced by international development and local feminist networks, and the intersectional social position of lower-class trafficked women, which remains unquestioned by the case managers. This dual identity of trafficked women as at once deviant and vulnerable sanctions the systemic governance of their desires, particularly because policies, practices and discourses reproduce inequalities of gender and class. In what follows, I contrast the emancipatory discourse of survivorship with the daily practices of control and surveillance. By describing three ways of disciplining desire, that is, directing desire, regulating dangerous desires and rehabilitating desires, I show how gender and class-based assumptions construct the ideal disciplined survivor.

According to Nandi, the NWA Director of Projects, and Musharraf Huq, the Project Manager, the NWA shelter is one of a kind because its cornerstone is respect for survivors. There are three 'house mothers', one for each floor of the building. There are also six case managers. According to Nandi, 'We try our best to make this a gender-friendly atmosphere.' By this, they meant that almost all the case managers are women, though there are over twenty male children. One case manager explained to me,

There are no victims here. Only survivors. The survivors here get access to nutritional food, medical care, and psychological counselling. There are individual counselling sessions and group ones. In the group therapy sessions, we also teach them 'life-skills'-like how to make good decisions, how to deal with hardship. We tell them that it is not their fault that they were sold into the sex trade or that they were sexually abused by their employers—even their own families... We tell them that if they follow the rules here, and learn all the skills we provide them, they will be able to make better decisions in the future.

At our very first meeting, the Executive Director, Taslima Tariq, explained some of the core principles of the organisation. Tariq made it clear that this position was a key feature of the organisation's philosophy. She continued,

You will see that our programmes are very progressive. We fought the government when they tried to restrict women from migrating. I'm sure you've heard that the genius politicians decided that the way to protect our women would be to stop them from migrating at all. What are these women supposed to do? They are poor women. All these idiots managed to do is push migration underground.

22 S Timmermans and I Tavory, 'Theory Construction in Qualitative Research: From grounded theory to abductive analysis', Sociological Theory, vol. 30, issue 3, 2012, pp. 167-86. 
She also stressed that they do not take a 'rescue' approach to trafficking victims ${ }^{23}$ and that their agenda is to advocate for the right of safe migration for women. ${ }^{24}$ That is to say, they do not believe that women are passive victims and have no agency in the migration process. NWA training material for a group of police officers in Jessore indicated that women are often voluntary migrants and not victims.

At a focus group with trafficking survivors, all aged between 17 and 23 , several explained that they would migrate again. Sheila said, 'Of course, I will cross the border again. Coming to NWA, talking to these apas ('big sisters', referring to the NGO staff), I have gotten smarter. I won't get trafficked again because I know whom to trust. Once they let me go, I want to go to India. I know how to dress now to look like an Indian so the guards won't get me.' In reply, Hasina explained, 'You will get in trouble if you don't have the right papers to cross the border. I didn't have papers. I was dumb. But I learned here that the people who put me on the bus to India are traffickers. What happened to me was not my fault. Society calls me nosto (corrupted) for selling my body, but it's society that put me in this place.' Such assertions indicate that the NWA has a feminist analysis that understands trafficking as a case of structural violence and respects the right of women to migrate, and they have managed to convey it to the survivors in the shelter. However, this understanding contradicts the everyday practices of disciplining women inside the shelter.

\section{Regulating Dangerous Desires}

Workers at Café Mukti were paid biweekly, but their money was 'kept safe' with their case managers. I witnessed case managers telling women that wearing make-up attracts the wrong kind of attention. They clarified - both for the women and for me, when I asked for an explanation-that the women should not develop a taste for expensive things like brand-name shampoo because it was outside the means of the lowwage work they were being trained to do. The case managers told the survivors that this would tempt them to re-enter sex work so they could buy expensive beauty products; I witnessed case managers explicitly citing this logic to deny women access to the money they earned.

Regulating the purchase of shampoos and cosmetics reinforces the notion that these women need protection from their own dangerous desires. Since carnal desires are seen as inherent to lower-class or deviant women, this means that they will never be able to fully realise their status as survivors. Such practices disciplined women into traditional gender norms. Moreover, despite repeated assertions that these are survivors, not victims, their 'past' or their 'trauma' were regularly brought up in order to justify their surveillance. Desire for consumer goods as well as sexual desire seems to hover over the shelter like a dark spectre. When I asked one of the counsellors, Taslima, why some of the women had attempted to escape, she immediately cited 'addiction to sex' as the number one reason. Thus, it appears that the shelter staff view these women as inherently damaged, incapable of becoming disciplined survivors.

Such attitudes reveal that while the NWA staff at all levels are adept at a feminist discourse, they share commonly held views about these women as damaged goods, victims of their own dangerous desires. As the counsellor further explained, 'It's difficult for women like us to understand, but some of these girls...are addicted to sex. That's the thing with people of a certain level of society; they are weaker and more vulnerable to moral dangers.'

Another case manager, Tariq, a man who had been working at NWA for over ten years, also told me,

This is difficult for me to say to a civilised woman like you, but you are a researcher, so I will be honest with you. Some of these lower-class women, even the ones who were trafficked into the sex trade through violence, eventually develop a taste for sex. Once they have been with multiple men, they can never go back to being with only one. Why do men go to prostitutes? To do

23 There are primarily two ways in which survivors come to the NWA's shelter: the first is through official channels and the second is through victims' families. In the first instance, the police contact NWA if they suspect someone of having been trafficked. This often requires NWA leadership to travel to India or another destination country to identify a victim and secure his or her repatriation. Subsequently, a Bangladeshi court issues an order to keep the victim in NWA custody if she/he is a minor and the family does not come forward or if the court suspects that returning the victim to the family may be dangerous.

24 As a part of 'life skills' training, women are taught how to acquire passports and visas through legal means and how to identify travel agencies that are fronts for traffickers. 
things to them they cannot do to their wives. So, these girls in prostitution get exposed to things like anal and oral sex and they cannot live without it. This is the harsh truth that rehabilitation cannot repair.

On another occasion, the same case manager confessed to me: 'I don't know why these women get pregnant...if it were up to me, I would make sure they all got their tubes tied when they arrived at our shelter.' Thus, the respect for agency professed by the organisation's public stances is trumped by the assumed deviancy of the women due to their age, gender, class and experience of trafficking in the minds of the case managers.

Significantly, there were no discussions of safe sex with the survivors and I found no mention of this topic in any of the organisation's training manuals. One case manager admitted, 'We mention condoms sometimes during our one-on-one case meetings. But some of us are afraid that mentioning sex will put the wrong ideas in their heads.' Thus, it appears that there is a tendency to view survivors as incapable of handling information about sexuality and treating them as both deviant as well as vulnerable.

\section{Directing Desires}

During my time at the organisation, the shelter hosted Western officials from funding agencies, including the USAID and Save the Children (Denmark), on two occasions. I found that the leaders and case managers directed the survivors to participate in particular activities where the desire of the survivors to seek resilience through various therapeutic activities would be on display; thereby, performing the disciplined survivor. The organisation projected therapeutic programmes as one of the strengths of the shelter because the language of therapy is legible to Western funders. In the weeks leading up to the first visit, the youngest of the women were taught a Bengali folksong and dance, which they performed at a welcome ceremony. For the purposes of the event, the women were given colourful sarees and had their make-up done. After the spirited performance, the Executive Director mentioned the benefits of dance as a way to cope with trauma. This comment made it seem like dance therapy was a regular part of the shelter's activities, when in fact the women learnt this routine specifically for this event. While most of the women expressed either apathy or anxiety about the performance, some of them told me they were excited that NWA staff finally permitted them to wear make-up, even if it was only for this performance. Dancing to a folk song that celebrates rural Bangladesh for the Western gaze draws on orientalised notions of the Bangladeshi womanhood, which is characterised by sweetness and innocence. This performance is meant to make the funders feel as though they were able to have a more authentic experience by witnessing and enabling the resilience of the survivors.

On another occasion, I found a survivor who was sitting in the corner of the dormitory with a sewing project in her hands, looking morose. I knew that this woman always avoided craft classes, so I asked her what she was doing. She told me that a case manager instructed her to pretend to be creating an embroidery so that when the funders walk through the dormitory, they can see an example of survivors engaging in sewing in their free time because they find it therapeutic. In this instance, the case workers, under the leadership of the Executive Director, attempted to project the vision of disciplined survivors as those who were willing to engage in the proper modes of rehabilitation. By directing such moments of orchestrated desire for resilience, the NWA aimed to deliver a neatly packaged redemption story for funders.

\section{Rehabilitating Desire}

Finally, when I asked NWA staff how they decide on what kind of vocational training to provide the women, they answered, 'It's all about what is marketable. We can't train them to do things they will not be hired for, so we mostly stick to sewing.' Sewing lessons are interchangeably referred to by the staff as 'craft therapy' and 'skills training'. Yet, staff at NWA also admitted to me that the sewing lessons the women received would only train them for entry-level work at garment factories, which practically guarantees very low income and risky labour conditions and a high chance of returning to sex work. The staff expressed frustration that they were training these women for low-wage work with little likelihood of advancement, but also stated that there were few other options available for working-class women.

I asked about the driving programme they once had for trafficking survivors. I was told, 'That didn't last very long. Our own NGO sisters refused to ride in cars driven by women, so how can you expect others to? Besides, driving is not a safe vocation for women, particularly these women. They have already been 
traumatised, so they are prone to fall into the wrong hands, and Allah knows what may happen. Our first priority is always safety and protection.' The refusal to ride in cars driven by these women brings out the staff's fear that they are unfit because they are women, lower class and victims of sexual violence. Another staff member noted that since there are very few female taxi drivers in Dhaka, teaching these women to drive will expose them to further stigma as it would violate gender norms.

Contrastingly, when I asked the survivors how they would feel about the opportunity to train as taxi drivers, Hasina, 23, explained, 'If you asked me if I would become a driver when I was still in the village, I would laugh and tell you, "Why would I ruin myself by working outside in a man's profession?" But now that I have already been "ruined", I don't have to worry about that...I have nothing to lose. So, I can do whatever I want.' Another young woman, Maria, added, 'I think it would be good to have women taxi drivers. That way other women can go around the city without worry. If I were a driver, I would only take female passengers. That would be ok.' This comment not only reflects a feminist aspiration that breaks patriarchal social norms, but also the fact that she sees her experience with trafficking as a learning experience and one that prompts her to be a part of the solution so that others do not face the same risks. While the survivors at the shelter are receiving some training in sewing and retail, traditional notions about proper gender roles and anxiety about sexual deviance are barriers to opportunities for higher paying work.

The women are also discouraged from going into beauty salon work. As one of the NGO staff explained:

Those places are the worst. Either the clients will treat them like garbage, or the girls will get addicted to cosmetics and consumeristic things. Addiction to cosmetics is bad because it leads to other kinds of temptations. This is how women fall into the trap of sex work. They see things they cannot afford, and then they become tempted to do anything to make enough money to buy them... and these girls are already vulnerable to the sex trade. It is a precarious place they are in. Anything can push them over the edge.

Once again, it is clear that concerns for the 'safety and protection' of trafficking survivors mediate the kind of work they are allowed to pursue. The discourse on safety and protection is heavily gendered and class-based. Employment in the beauty salons is seen as dangerous because enhancing their looks will allegedly enhance their inherent tendencies to be 'temptresses', which arguably leads them into the arms of traffickers. Moreover, the counsellor's use of the phrase 'trapped in sex work' reveals her true attitude to sex work and contradicts the leadership's claim that the organisation supports sex workers' rights. This tension is reflected in the fact that sex work is a contentious point among board members and that, in spite of expressing the view that sex work is work during my interviews, the leadership claimed they could not actively engage with sex workers because in order to qualify for funding from the US, the organisation could not be perceived to be supporting sex work.

Café Mukti, funded by the IOM, is one of NWA's most widely touted programmes. Several of the staff spoke with great enthusiasm about this two-year pilot project. The Café was located in the government compound that houses the Ministry of Women and Children. It is run by four or five formerly trafficked women between the ages of 18 and 24 . As the project supervisor explained to me, 'These girls learn important skills like accounting and interpersonal skills. The important thing is that they get exposure to being in a professional setting. It builds confidence. These young women forget that they were once stigmatised, and they learn the importance of earning their own money.'

NWA staff seek to empower these women by creating economic and social integration opportunities. When pressed about what career prospects these women would have once the project ended, the staff made vague claims such as: 'They will have skills; they can do anything they want. Maybe NWA will give them micro-loans to start their business.' While these women spent a long time being trained in how to run the Café, they were not given any advice on how they can apply for loans and set up a new business. As one of the shelter staff pointed out to me, "Notice the way they are dressed. No one will treat them like victims in those clothes. They look professional, not like servants. Wherever they go, they can say: "We work for NWA, for Café Mukti." Having a job like that changes your whole identity, how you see yourself. You think any of them will ever think about going back to the brothel? I doubt it.' NWA recognises that, in Bangladesh, women from the village who lack formal education are seen by urban professionals as less than competent. Therefore, it is not the skills, but the presentation of self that hides their class, which is important. 


\section{Conclusion}

In this article, I argue that disciplining desire captures how NGO employees make claims of empowering survivors of trafficking while advancing a project of gender- and class-normative assimilation. This ethnography of a Bangladeshi shelter particularly reveals the tensions between claims of empowerment and the ways organisations undermine their liberatory objectives, in part because of their accountability to Western funding structures and priorities, and the ways these forces manifest in everyday practices of social control. I proffer a typology of disciplining desire as a point of departure for future work which might consider the other ways in which poor women's desires are perceived, not simply as dangerous to their own survival, but as fundamentally upsetting the existing social order. Therefore, if we understand disciplining desire as forcing poor women in the Global South in their perceived proper position within existing social hierarchies, we make visible how the bureaucratisation of rescue and reintegration of trafficking survivors reinforces existing social relations as seemingly natural and collectively desirable. In particular, this paper shows that such marginalisation is not only a process of repression, but one that actively cultivates an ideal survivor subjectivity- that of a disciplined survivor. As a consequence, this process places constraints on the opportunities available for these women to not only survive but to thrive. This account encourages researchers to critically consider the micro-interactions that undermine the emancipatory goals within women's empowerment regimes in the Global South.

Diya Bose is a PhD candidate in Sociology at the University of California, Los Angeles. Her research interests address the intersections of gender, sexuality, labour and social justice movements. Her current research focuses on the biopolitics of the state recognition of Third Gender identity in India. Email: diyab@ucla.edu 